\title{
Vehicle Trip Reduction Impacts of Transit-Oriented Housing
}

\author{
Robert Cervero, University of California, Berkeley \\ G. B. Arrington, PB Placemaking
}

\begin{abstract}
A survey of 17 transit-oriented developments (TOD) in five U.S. metropolitan areas showed that vehicle trips per dwelling unit were substantially below what the Institute of Transportation Engineer's Trip Generation manual estimates. Over a typical weekday period, the surveyed TOD housing projects averaged 44 percent fewer vehicle trips than that estimated by the manual (3.754 versus 6.715). Vehicle trip rates of transit-oriented housing projects were particularly low in metropolitan Washington, D.C. and Portland, Oregon, both known for successful TOD planning at the regional and corridor levels. Trip rates also generally fell as neighborhood densities increased. Local officials should account for the lower automobile use of those residing in TOD housing through such measures as traffic impact-fee adjustments and reduced offstreet parking requirements.
\end{abstract}

\section{Introduction}

The widest knowledge gaps on the effects of transit-oriented development (TOD) on travel demand are in estimating vehicle trip generation rates. Many TOD proposals have been abruptly halted or redesigned at lower densities due to fears that dense development will flood surrounding streets with automobile traffic. Part of the problem lies in the inadequacy of current trip generation estimates, which are thought to overstate the traffic-inducing impacts of TOD. Institute of Transportation Engineers (ITE) trip generation rates are the standard by which local traffic 
impacts are typically estimated and impact fees are set. Some analysts, however, have identified a serious "suburban bias" in the current ITE rates (Ewing et al. 1996; Shoup 2002). Typically, the data used to set trip rates are drawn from suburban areas with free and plentiful parking, low-density, single land uses, and minimal transit services. Moreover, ITE's auto trip reduction factors, used to reflect internal trip capture, are based on only a few mixed-use projects in Florida; there has been little or no observation of actual TODs. The end result is that the traffic impacts of TODs are often overstated. This can result in TOD developers paying higher impact fees, proffers, and exactions than they should. Smart growth requires smart calculations; thus, impact fees need to account for the likely (borrowing a term used in the United Kingdom) "trip de-generation" effects of TOD.

Empirical evidence on trip generation also can inform the setting of parking requirements near transit stations. Developers and financial institutions still prefer conventional parking ratios in TODs (Cervero et al. 2004). Most TODs are thus parked oblivious to the fact that a rail stop is nearby and, as a result, their potential traffic-reducing benefits are muted. Structured parking, in particular, has a significant impact on development costs and is prohibitively expensive in many markets. Lower TOD parking ratios and reduced parking could reduce construction costs, leading to somewhat denser TODs in some settings.

\section{Study Focus}

This article summarizes the results of a recent Transit Cooperative Research Program (TCRP) study that examines vehicle trip generation rates for a representative sample of 17 multi-family housing projects of varying sizes near rail transit stations in four parts of the country: Philadelphia/northeast New Jersey; Portland, Oregon; metropolitan Washington, D.C.; and the East Bay of the San Francisco Bay Area. Rail services in these areas are of a high quality and span across four urban rail technologies: commuter rail (Philadelphia SEPTA and NJ Transit); heavy rail (San Francisco BART and Washington Metrorail); light rail (Portland MAX); and streetcar (Portland).

The most current ITE Trip Generation manual (2003) includes data for nearly 1,000 land uses and combinations; however, the focus of this research is on residential housing. The research aims to seed the ITE manual with original and reliable trip generation data for one important TOD land use-residential housing - with the expectation that other TOD land uses and combina- 
tions will be added later. We also hope the research prompts local officials to challenge how they evaluate the likely traffic impacts of housing near major rail transit stations as well as the parking policies set for these projects. Lower levels of automobile travel among those living in transit-oriented housing is thought to come from three major sources: (1) residential self-selection, wherein for lifestyle reasons people consciously seek out housing near major transit stops for the very reason they want to regularly take transit to work and other destinations; studies in California suggest as much as 40 percent of the mode choice decision to commute via transit can be attributed to the self-selection phenomenon (Cervero 2007); (2) the presence of in-neighborhood retail sited between residences and stations that promote "rail-pedestrian" trip-chaining; an analysis of the American Housing Survey suggests that the presence of retail near rail stations can boost transit's commute mode share by as much as 4 percent (Cervero 1996); and car-shedding (i.e., the tendency to reduce car-ownership when residing in efficient, transit-served locations) (Holtzclaw et al. 2002).

For studying traffic impacts of housing near rail stations, we selected mainly multifamily (rental) apartments and, in one instance, an owner-occupied condominium project. Table 1 provides background information on the selected TOD housing. Projects ranged in size from 90 units (Gresham Central Apartments in Portland) to 854 units (Park Regency in the East Bay city of Walnut Creek). Most projects were garden-style in design and 3-4 stories in height. The sampled Washington Metrorail housing projects, however, tended to have much higher densities, with the exception of the four-story Avalon apartments near the Bethesda Metrorail station. The average number of parking spaces per project was around 400, yielding an average rate of 1.16 spaces per dwelling unit. Six of the surveyed housing projects had ground-floor retail and/or commercial uses; however, all were primarily residential in nature (i.e., over $90 \%$ of gross floor area was for residential activities). One criterion in selecting projects to survey was that the project not be immediately accessible to a freeway interchange. All of the sampled projects were more than 500 feet from a freeway entrance; five were situated within a quarter mile of a freeway on-ramp. The average walking distance from the project entrance to the nearest rail station entrance was 1,060 feet.

\section{Methods and Analyses}

To compile empirical data on vehicle trip rates for the 17 TOD housing projects, approval was first obtained from property owners and managers to allow the 


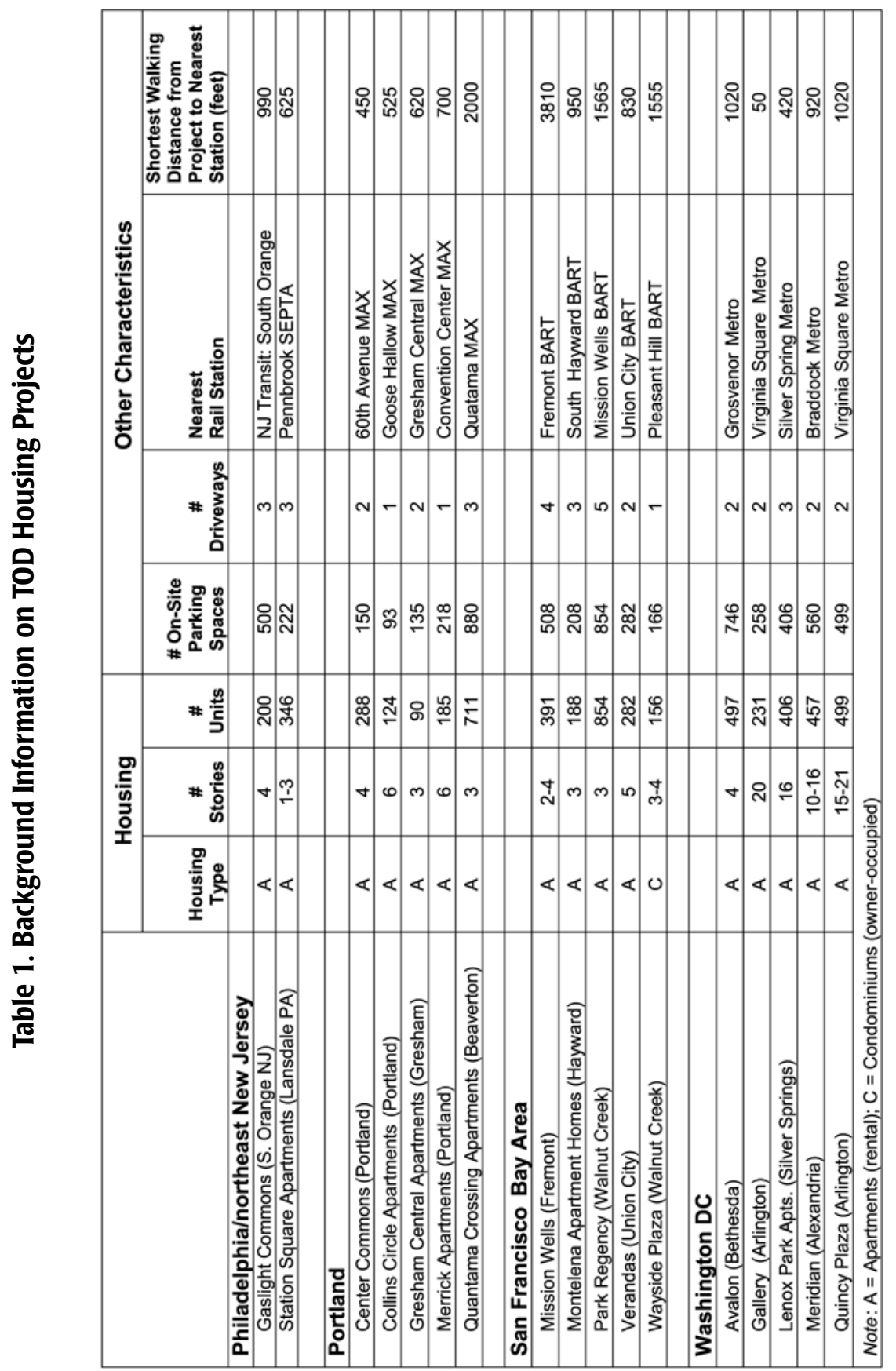


installation of pneumatic-tube recorders at all curb cuts and driveways to surveyed projects. Local traffic engineering firms that specialize in vehicle trip datacollection were contracted to set up the tube counters and compile data. Two consecutive days in late May 2007 were chosen to compile tube-count data that corresponded with peak conditions: middle of the week and prior to the summer vacation season.

The vehicle count data obtained in the field were converted to 24-hour as well as $A M$ and PM peak-hour rates per dwelling unit for each project. The computed rates for TOD housing projects were compared to those found in the latest edition of the ITE manual for the equivalent land use (i.e., apartments and condominiums). Comparisons were drawn using the ITE manual's "weighted averages" as well as estimates derived from best-fitting regression equations. Multivariate regression equations also were estimated for predicting the trip generation rates of TOD housing as a function of explanatory variables. The article closes with discussions on the public-policy implications of the research findings.

\section{Comparison of Vehicle Trip Generation Rates}

TOD housing clearly "de-generates" trips in the urbanized areas studied. Below, results for both 24-hour periods as well as peak periods are summarized.

\section{Average Weekday Trip Rate Comparisons}

Table 2 shows that, in all cases, 24-hour weekday vehicle trip rates were considerably below the ITE average rate for similar uses. Taking the unweighted average across the 17 case-study projects, TOD housing projects generated around 47 percent less vehicle traffic than that predicted by the ITE manual ( 3.55 trips per dwelling unit for TOD housing versus 6.67 trips per dwelling unit by ITE estimates). This held true using both the weighted average ITE rate and the ITE rates predicted using the best-fitting regression equations.

The largest vehicle trip reduction was found in the Washington, D.C. metropolitan area. Among the five mid- to high-rise apartment projects near Metrorail stations outside the District of Columbia, vehicle trip generation rates were more than 60 percent below that predicted by the ITE manual. There, 24-hour vehicle trip rates ranged from a high of 4.72 trip ends per dwelling unit at the more suburban Avalon project near the Grosvenor Metrorail Station (and outside the beltway) to a low of around one vehicle trip per weekday for every two dwelling units at the Meridian near Alexandria's Braddock Station. The comparatively low vehicle trip 
generation rates for TOD housing near Washington Metrorail stations are consistent with recent findings showing high transit modal splits from a 2005 survey of 18 residential sites (WMATA 2006). For projects within $1 / 4$ mile of a Metrorail station (which matched the locations of all the five TOD housing projects we studied in the Washington metropolitan area), on average, 49 percent of residents used Metrorail for their commute or school trips. One of the projects we surveyed-the Avalon apartments at Grosvenor Station-also was surveyed in the 2005 WMATA study. The Avalon, which had the highest trip generation rate among the five projects surveyed in the Washington area, had an impressively high work- and school-trip transit modal split in the 2005 WMATA survey-54 percent-given its comparatively lower-density, car-oriented setting. High ridership levels and vehicle-trip suppression in metropolitan Washington are tied to the region's success in creating a network of TODs, highlighted by the Rosslyn-Ballston corridor (Cervero et al. 2004). Synergies clearly derive from having transit-oriented housing tied to transit-oriented employment and transit-oriented shopping along many Washington Metrorail corridors.

After the Washington area, TOD housing in the Portland area tended to have the lowest weekday trip generation rates-on average, around 40 percent below that predicted by the ITE manual. The range of experiences, however, varied, from a low of 0.88 weekday vehicle trips per dwelling unit for Collins Circle in downtown Portland to a high of 6.34 for more suburban Quantama Crossing (only slightly below the average rate from the ITE manual and a bit above the regression-generated estimate from the ITE manual).

Among the surveyed Portland-area apartments, also notable for a low trip generation rate are the Merrick Apartments near the MAX light rail Convention Center station in the Lloyd District, across the river from downtown Portland: 2.01 weekday vehicle trips. Travel behavior of the residents of the Merrick Apartments also was studied in 2005 (Dill 2005). Based on a 43 percent response rate from 150 surveyed households at the Merrick Apartments, trip generation estimates can be imputed from that survey. The 2005 survey asked: "In the past week (Saturday, January 29 through Friday, February 4), how many times did you go to the following place from your home in a vehicle, walking, bicycling, riding the bus, or riding MAX light rail? Each time you left your home during the week is a trip." From household responses, an average of 1.42 daily vehicle trips per dwelling from the Merrick Apartments was made. Doubling this rate (assuming those who drove away each day also returned) yields an estimated daily rate of 2.84 vehicle trips 


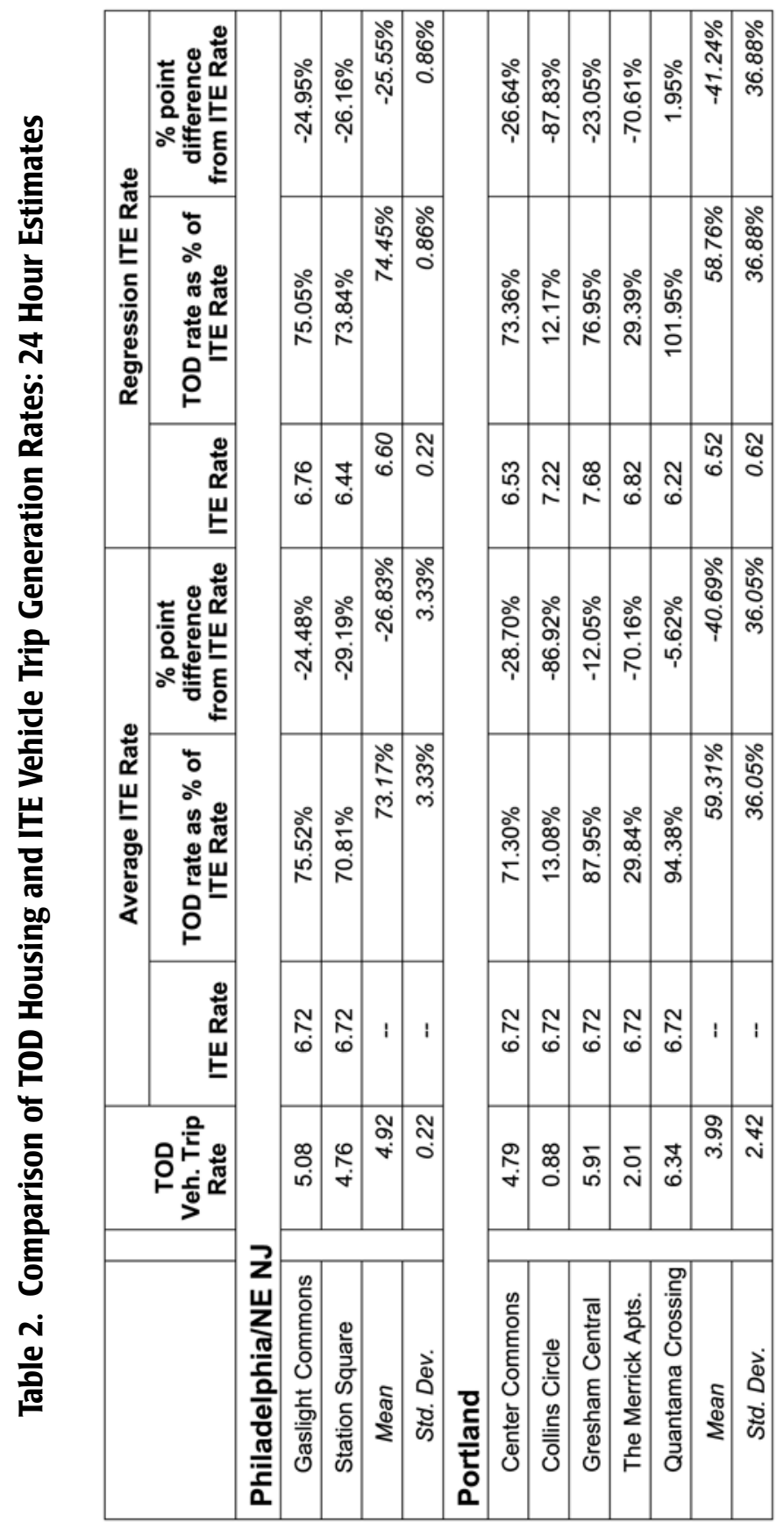




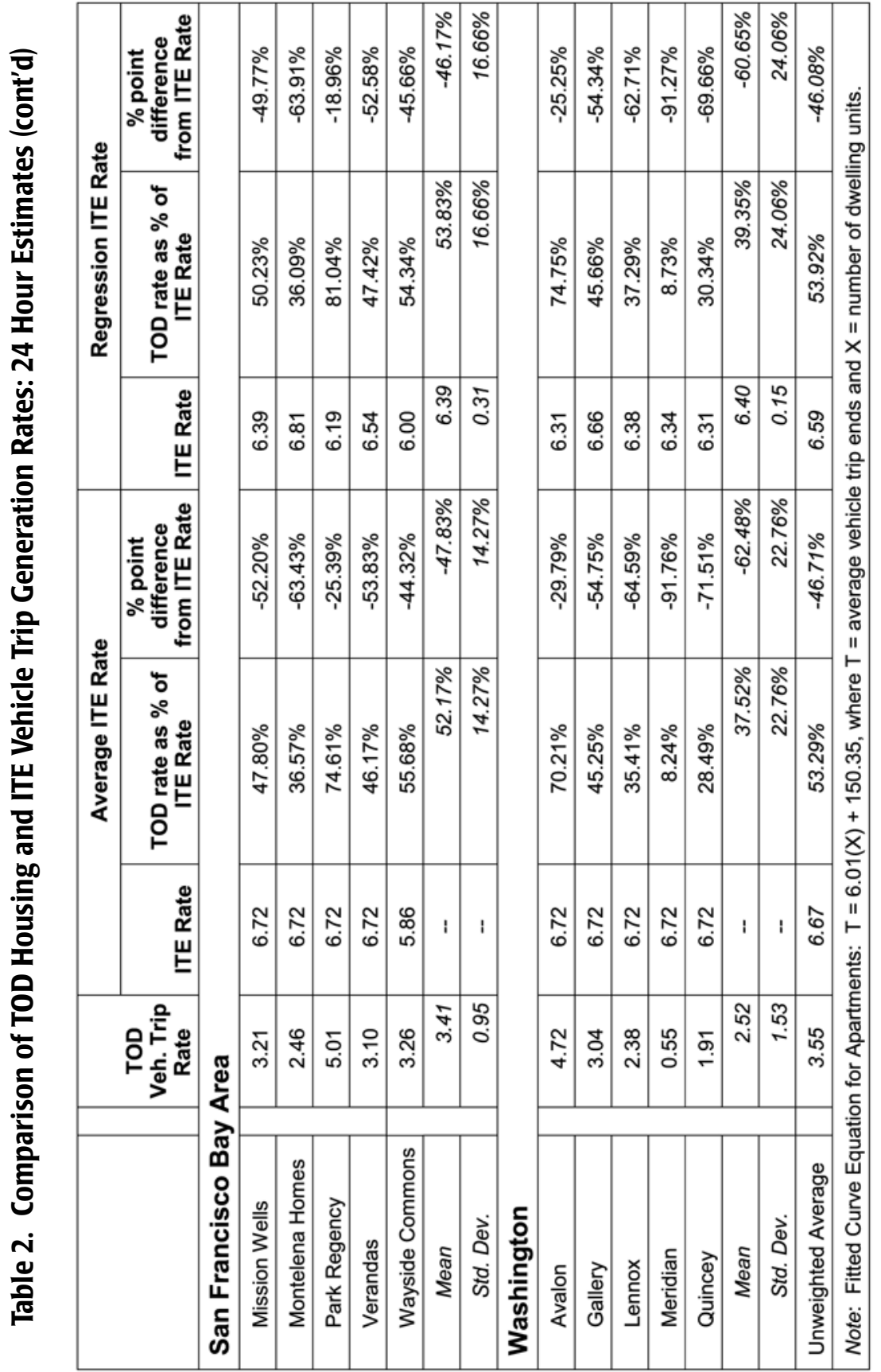


per dwelling unit. This is bit higher than that found in our tube count survey but still substantially lower than the ITE rate. The 2005 survey also estimated that 18 percent of all trips made by residents of the Merrick Apartments were by transit (both rail and bus). For work and school trips, transit's estimated modal split was 23 percent.

Just as in the case of metropolitan Washington, Portland's success at "de-generating" vehicle trips around transit-oriented housing cannot be divorced from the regional context. High ridership and reduced car travel at the surveyed housing projects stems to a significant degree from the successful integration of urban development and rail investments along the Gresham-downtown-westside axis. In Portland, as in Washington, TODs are not isolated islands, but rather nodes along corridors of compact, mixed-use, walking friendly development-the so-called "necklace of pearls" urban form.

The San Francisco Bay Area also averaged vehicle trip generation rates substantially below those estimated by the ITE manual. Among the East Bay TOD housing projects studied, Montelena Homes (formerly called Archstone Barrington Hills) had the lowest weekday rate: 2.46 vehicle trip ends per dwelling unit, 63 percent below ITE's rate. A 2003 survey of residents of this project found very high transit usage: 55 percent stated they commute by transit (both rail and bus) (Lund et al. 2004). The 2003 found the following commute-trip transit modal splits (compared to our recorded weekday trip rates): Wayside Commons-56 percent (3.26 daily trips per dwelling unit); Verandas -54 percent (3.1 daily trips per dwelling unit); Park Regency-37 percent (5.01 daily trips per dwelling unit); and Mission Wells-13 percent ( 3.21 daily trips per dwelling unit).

Finally, the two apartment projects near suburban commuter rail stations outside of Philadelphia and the Newark metropolitan area of northeast New Jersey averaged weekday vehicle trip generation rates that were roughly one-quarter less than that predicted by the ITE manual. This is an appreciable difference, given the relatively low-density settings of these projects and the fact that commuter rail offers limited midday and late-night services.

\section{Peak Period Trip Rate Comparisons}

Differences in vehicle trip generation rates during peak hours were quite similar to those found for the 24-hour period. In general, denser, more urban TOD housing had the greatest peak-hour trip rate differentials. For example, the PM trip rates 
for Portland's Collins Circle and Alexandria, Virginia's Meridian projects were 84.3 percent and 91.7 percent below ITE predictions, respectively.

\section{Weighted Average Comparisons}

The results presented above were based on unweighted averages-i.e., each project was treated as a data point regardless of project size. The ITE manual, however, presents "weighted averages" of trip generation by summing all trip ends among cases and dividing by the sum of dwelling units. Thus, for "apple to apple" comparisons, weighted average vehicle trip rates were computed for all 17 projects combined for weekday, AM peak, and PM peak. Figure 1 summarizes the results. Over a typical weekday period, the 17 surveyed TOD housing projects averaged 44 percent fewer vehicle trips than that estimated by the ITE manual ( 3.754 versus 6.715). The weighted average differentials were even larger during peak periods49 percent lower rates during the AM peak and 48 percent lower rates during the PM peak. To the degree that impact fees are based on peak travel conditions, one can infer that traffic impacts studies might end up overstating the potential congestion-inducing effects of TOD housing in large rail-served metropolitan areas by as much as 50 percent.

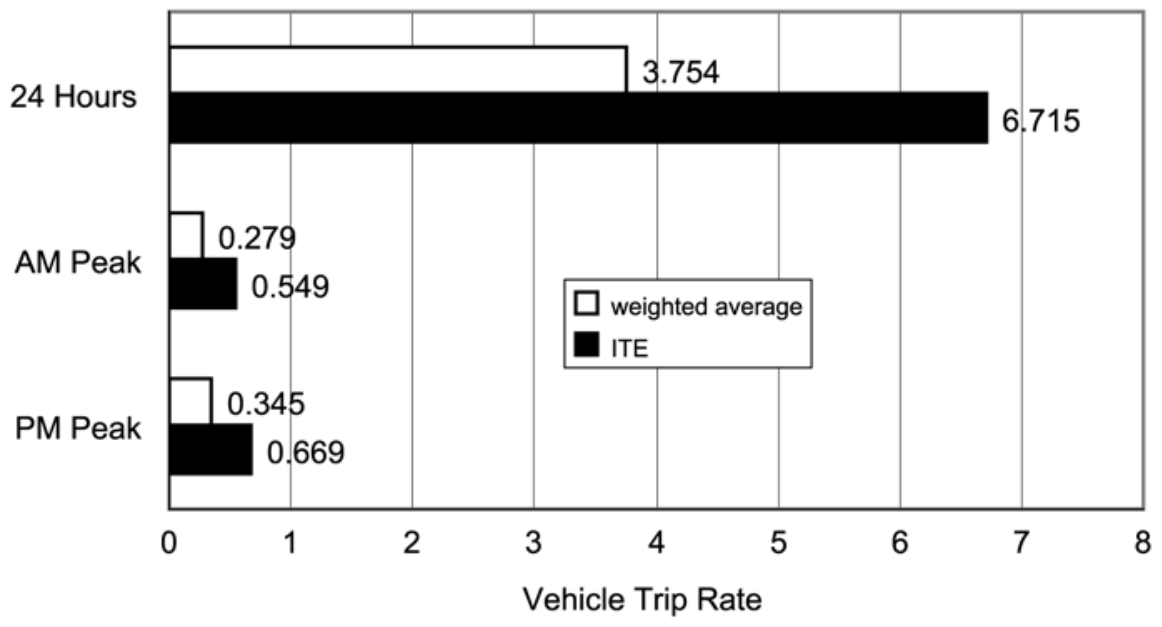

Figure 1. Comparison of Weighted Average Vehicle Trip Rates: TOD Housing and ITE Estimates 


\section{Scatterplots}

The ITE Trip Generation manual reports summary findings in a scatterplot form accompanied by best-fitting regression equations. Figure 2 shows scatterplot results for the 17 surveyed TOD housing projects for the weekday period. Linear plots fit the data points reasonably well, explaining over two-thirds of the variation in vehicle trip ends. We note that the Merrick Apartments in Portland stands as an outlier, producing far fewer vehicle trip ends relative to its project size than the other TOD housing projects. Omitting this single case improved the regression fit considerably, increasing the R-square statistic to 0.829 .

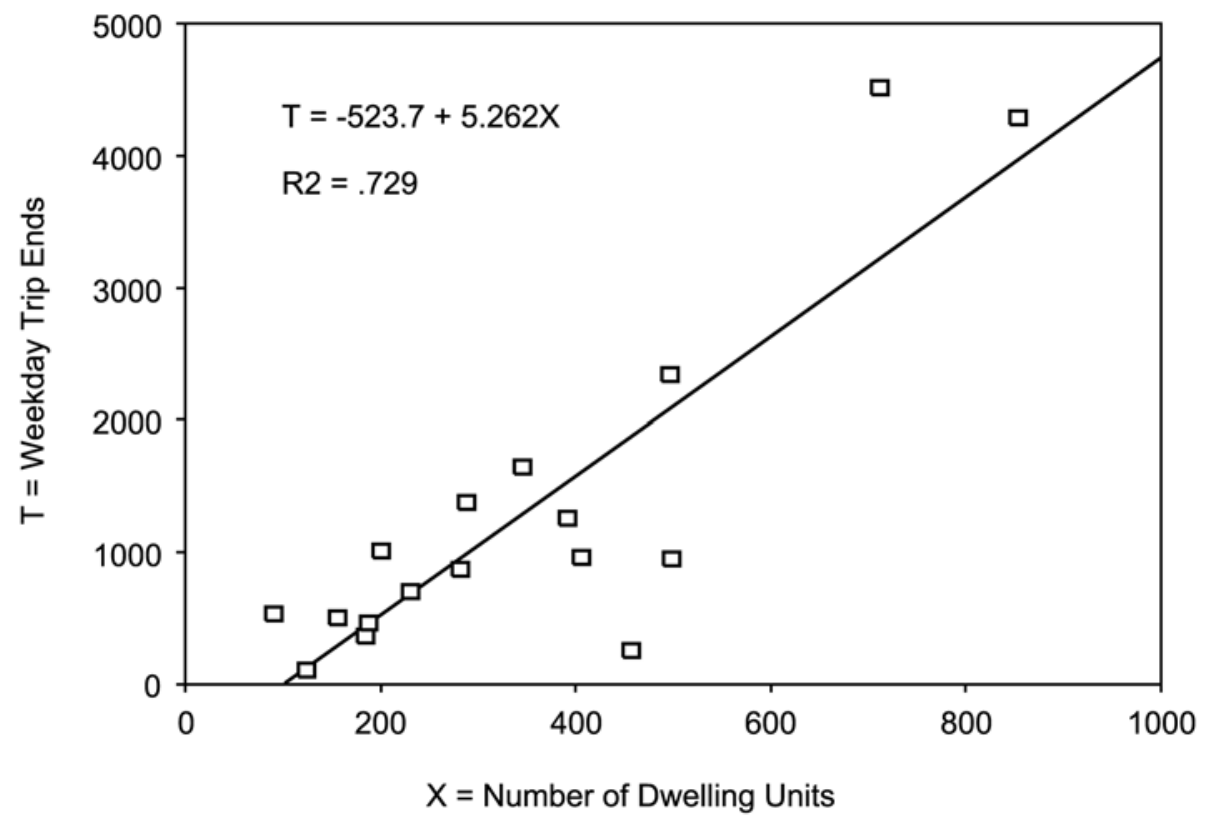

Figure 2. TOD Housing Weekday Vehicle Trip Ends by Number of Dwelling Units

\section{Factors Influencing TOD Housing Trip Generation Rates}

Trip generation rates among the 17 sampled TOD housing projects varied most strongly as a function of surrounding residential densities-i.e., the number of dwelling units per gross acre within a $1 / 2$ mile radius of the rail station closest to the project, estimated from the 2000 census. Figure 3 shows that PM trip generation 
rates for TOD housing decline as surrounding residential densities increase, yielding the following bivariate regression equation:

Vehicle Trips per Hour, PM Peak (est.) =

$0.493-.019$ (Dwelling Units per gross acre within $1 / 2$ mile of nearest station);

$\mathrm{R}^{2}=0.45$.

Residential density is likely serving as a broader surrogate of "urbanicity"-i.e., denser residential settings tend to have nearby retail and other mixed-use activities, better pedestrian connectivity, and often a more socially-engaging environment, all factors that moderate automobile travel.

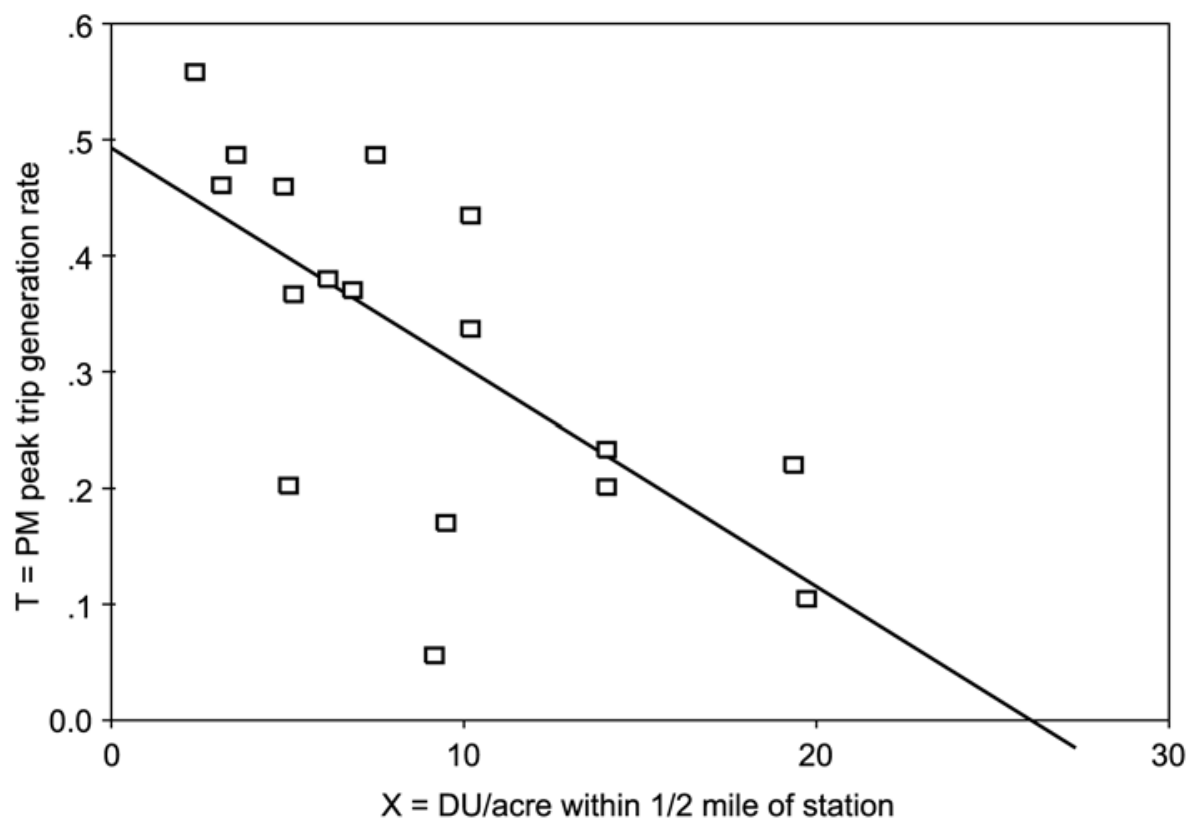

Figure 3. Scatterplot of PM Trip Generation Rate and Residential Densities for TOD Housing Projects

For the morning peak hour, a two-variable regression equation was estimated, showing that that vehicle trip generation rates fall not only with residential densities but also lower parking supplies (Table 3). The combination of higher neighborhood densities and less parking, which generally reinforce each other, holds promise for driving down morning vehicle trips for transit-based housing. 
A better fitting equation was produced for predicting PM peak trip rates as a proportion of ITE rates (Table 4). This model explained 63 percent of the variation. The equation reveals that TOD housing projects closest to the $C B D$, in higher density residential settings, and in neighborhoods with smaller household sizes averaged the lowest PM trip rates.

\section{Table 3. Best-Fitting Multiple Regression Equation for Predicting AM Peak Hour Trip Rates, TOD Housing Projects}

\begin{tabular}{|c|c|c|c|c|}
\hline & Ve & $\begin{array}{l}\text { Depend } \\
\text { icle Trips }\end{array}$ & $\begin{array}{l}\text { net Variable } \\
\text { er Hour, } \mathrm{A}\end{array}$ & \\
\hline & Coeff. & Std. Err. & t Statistic & Prob. \\
\hline $\begin{array}{l}\text { Residential Density: Dwelling Units per } \\
\text { Gross Acre within } 1 / 2 \text { mile of station }\end{array}$ & -0.012 & 0.006 & -1.926 & .075 \\
\hline $\begin{array}{l}\text { Parking Supply: Parking spaces per } \\
\text { Dwelling Unit }\end{array}$ & 0.094 & 0.074 & 1.279 & .222 \\
\hline Constant & 0.268 & 0.119 & 2.243 & .042 \\
\hline $\begin{array}{l}\text { Summary Statistics: } \\
\text { F statistics (prob.) }=3.800(.048) \\
\text { R Square }=.352 \\
\text { Number of Cases }=17\end{array}$ & & & & \\
\hline
\end{tabular}

Table 4. Multiple Regression Equation for Predicting PM Peak Trip Generation Rates as a Proportion of ITE Rate for TOD Housing Projects

\begin{tabular}{|l|c|c|c|c|}
\hline \multirow{2}{*}{} & \multicolumn{4}{|c|}{$\begin{array}{c}\text { Dependent Variable: } \\
\text { Vehicle Trips per Hour as a Proportion of } \\
\text { ITE Rate, PM Peak }\end{array}$} \\
\cline { 2 - 5 } & Coeff. & Std. Err. & t Statistic & Prob. \\
\hline Distance to CBD (in miles) & 0.013 & 0.005 & 2.631 & .021 \\
\hline $\begin{array}{l}\text { Residential Density: Dwelling Units per } \\
\text { Gross Acre within 1/2 mile of station }\end{array}$ & -0.026 & 0.009 & -2.893 & .013 \\
\hline $\begin{array}{l}\text { Household Size: Persons per Dwelling Unit } \\
\text { within 1/2 mile of station }\end{array}$ & -0.190 & 0.107 & -1.772 & .100 \\
\hline Constant & 0.964 & 0.264 & 3.657 & .003 \\
\hline $\begin{array}{l}\text { Summary Statistics: } \\
\text { F statistics (prob.) }=7.491 \quad(.004) \\
\text { R Square = .634 } \\
\text { Number of Cases }=17\end{array}$ & & & & \\
\hline
\end{tabular}


Using the regression results from Table 4, estimated PM trip rates for the TOD projects were plotted as a proportion of the rates predicted by the ITE manual (Figure 4). Assuming an average household size of 2 persons, the predicted values as a function of distance to CBD (horizontal axis) and residential densities (within $1 / 2$ mile of the nearest rail station, represented by the 5 lines) are shown in the figure. For example, the model predicts that, for a transit-oriented apartment 20 miles from the CBD in a neighborhood with 10 units per residential acre, the PM trip rate will be 55 percent of (or $45 \%$ below) the PM rate. If the same apartment in the same density setting were 5 miles from the $C B D$, the PM trip rate would be just 38 percent of the ITE rate. Another example: For two transit-oriented apartments 10 miles from the CBD, if the surrounding residential densities are 10 units per acre, the PM trip rate will be 45 percent of the ITE manual's rate. And if the surrounding densities are 20 units per acre, they will be just 20 percent of the rate, or 80 percent lower.

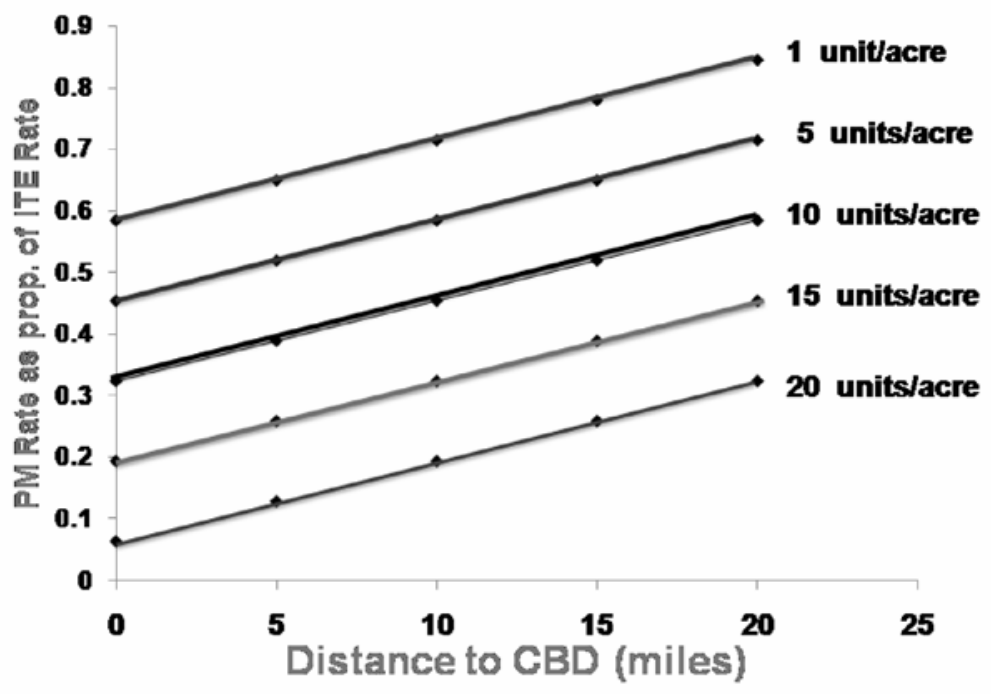

\section{Figure 4. Influences of Residential Densities and Distance to CBD on TOD Housing PM Trip Rates as a Proportion of ITE Rates}

\section{Conclusion}

Clear policy directions fall out of this research. The appreciably lower trip generation rates of transit-oriented housing projects call for adjustments in the measurement of traffic impacts. For peak periods (that often govern the design of roads 
and highways), this research shows transit-oriented apartments average around one half the norm of vehicle trips per dwelling unit. The rates varied, however, from 70-90 percent lower for projects near downtown to 15-25 percent lower for complexes in low-density suburbs. Regardless, smart growth needs smart calculus-those who build projects that lower the need to make vehicle trips should be rewarded in the form of reduced traffic impact fees and exactions. The expectation is developers would pass on some of the cost savings to tenants, thus making housing more affordable near rail stations.

The potential savings from a sliding-scale traffic impact fee could be substantial. In Sacramento, for example, the fee for multi-family housing with units in the range of 1,100 to 2,500 square feet is $\$ 4,477$ for an infill site to $\$ 10,372$ for a suburban setting. For a 700-unit infill site near one of Sacramento's light rail station, the cost savings from a 50 percent reduction in trip generation estimates could sum to nearly $\$ 1.6$ million.

To date, few jurisdictions have introduced sliding-scale fee structures to reflect the lowering of trip generation for TODs. Santa Clara County California's Congestion Management Agency has produced guidelines calling for a 9 percent trip reduction for housing within 2,000 feet of a light-rail or commuter-rail station. While this is a positive step, according to our research findings, this adjustment is a bit tepid. Similarly, the URBEMIS software program sponsored by the California Air Resources Board, used to estimate the air quality impacts of new development, calls for up to a 15 percent lowering of trip rates for housing in settings with intensive transit services-again, likely on the low side, based on our findings. More in line with the findings presented here are the vehicle trip reductions granted to the White Flint Metro Center project, a mega-scale, mixed-use joint development project now being built at Washington Metrorail's New Carrollton Station. With some 1.2 million square feet of office space, 250,000 square feet of commercialretail, and 375 residential units scheduled at build out, the project was granted a 40 percent reduction in estimated trip rates for the housing component based on proximity to transit.

The trip-reducing benefits of TOD call for other development incentives, such as flexible parking codes, market-responsive zoning, streamlining the project review and permitting process, and investments in supportive public infrastructure. Evidence of trip de-generation also suggests TODs are strong markets for carsharing. Recent research in the San Francisco Bay Area reveals that those who participate in carsharing lower their car ownership levels by around 10 percent, with higher 
vehicle-shedding rates among those living near rail stations (Cervero et al. 2007). The combination of reducing off-street parking and increasing carsharing options would yield other benefits, including reducing the amount of impervious surface (and thus water run-off and heat island effects) and the creation of more walkable scales of development. Such practices are not heavy-handed planning interventions but rather market-oriented responses-namely, efforts to set design standards and provide mobility options that are in keeping with the market preferences of those who opt to live near rail transit stations.

\section{References}

Cervero, R. 1996. Mixed land uses and commuting: Evidence from the American Housing Survey. Transportation Research A 30 (5): 361-377.

Cervero, R. 2007. Transit oriented development's ridership bonus: A product of self selection and public policies. Environment and Planning A 39: 2068-2085.

Cervero, R., G. Arrington, J. Smith-Heimer, R. Dunphy, and others. 2004. Transit Oriented Development in America: Experiences, Challenges, and Prospects. Washington, D.C.: Transit Cooperative Research Program, Report 102.

Cervero, R., A. Golub, and B. Nee. 2007. City CarShare: Longer-term travel-demand and car ownership impacts. Transportation Research Record 1992: 70-80.

Dill, J. 2005. Survey of Merrick TOD Residents: Final Report. Portland: Portland Metro.

Ewing, R., M. DeAnna, and S. Li. 1996. Land use impacts on trip generation rates. Transportation Research Record 1518: 1-6.

Holtzclaw, J., R. Clear, H. Dittmar, D. Goldstein, and P. Haas. 2002. Location efficiency: Neighborhood and socio-economic characteristics determine auto ownership and use-studies in Chicago, Los Angeles, and San Francisco. Transportation Planning and Technology 25: 1-27.

Lund, H., R. Cervero, and R. Willson. 2004. Travel Characteristics of Transit-Oriented Development in California. Oakland, California: CalTrans Transport Grant.

Institute of Transportation Engineers. 2003. Trip Generation. Washington, D.C.: ITE.

Shoup, D. 2002. Roughly right or precisely wrong? Access, Spring, 20-25. 
Washington Metropolitan Area Transit Authority (WMATA). 2006. 2005 Development-Related Ridership Survey: Final Report, Washington, D.C.: WMATA.

\section{About the Authors}

ROBeRT CeRvero (robertc@berkeley.edu) is Professor and Chair of the Department of City and Regional Planning at the University of California, Berkeley. He was chief author of TCRP Report 102, Transit Oriented Development in America: Experiences, Challenges, and Prospects, and currently is conducting research and advising on transit-oriented development in China.

G.B. ArRIngton (Arrington@pbworld.com) is Principal Practice Leader for PB PlaceMaking in Portland, Oregon, having worked on numerous projects on integrating transit and land use in the United States, China, Australia, New Zealand, Dubai, and the Caribbean. He is one of the founders of the Rail Volution conference and an active member with the Congress for New Urbanism. 